\title{
Precipitation Pattern Determines the Inter-annual Variation of Herbaceous Layer and Carbon Fluxes in a Phreatophyte-Dominated Desert Ecosystem
}

\author{
Ran Liu, ${ }^{1}$ Ellen Cieraad ${ }^{2,3}{ }^{\text {Yan }} \mathrm{Li},{ }^{1 *}$ and Jie $\mathrm{Ma}^{1}$
}

\begin{abstract}
${ }^{1}$ State Key Lab of Desert and Oasis Ecology, Xinjiang Institute of Ecology and Geography, Chinese Academy of Sciences, 818 South Beijing Road, Urumqi, Xinjiang 830011, China; ${ }^{2}$ Landcare Research, PO Box 69040, Lincoln 7640, New Zealand; ${ }^{3}$ Institute of Environmental Sciences CML, Leiden University, Leiden, The Netherlands
\end{abstract}

\begin{abstract}
Arid and semi-arid ecosystems dominated by shrubby species are an important component in the global carbon cycle but are largely under-represented in studies of the effect of climate change on carbon flux. This study synthesizes data from longterm eddy covariance measurements and experiments to assess how changes in ecosystem composition, driven by precipitation patterns, affect inter-annual variability of carbon flux and their components in a halophyte desert community dominated by deep-rooted shrubs (phreatophytes, which depend on groundwater as their primary water source). Our results demonstrated that the carbon balance of this community responded strongly to precipitation variations. Both pregrowing season precipitation and growing season precipitation frequency significantly affected interannual variations in ecosystem carbon flux. Heavy
\end{abstract}

Received 13 July 2015; accepted 15 November 2015; published online 14 January 2016

Electronic supplementary material: The online version of this article (doi:10.1007/s10021-015-9954-x) contains supplementary material, which is available to authorized users.

Author contributions YL and RL conceived and designed the experiments. RL, EC, and JM performed the experiments and analyzed the data. All authors contributed to the writing the manuscript.

*Corresponding author; e-mail: liyan@ms.xjb.ac.cn pre-growing season precipitation (November-April, mostly as snow) increased annual net ecosystem carbon exchange, by facilitating the growth and carbon assimilation of shallow-rooted annual plants, which used spring and summer precipitation to increase community productivity. Sufficient pre-growing season precipitation led to more germination and growth of shallow-rooted annual plants. When followed by high-frequency growing season precipitation, community productivity of this desert ecosystem was lifted to the level of grassland or forest ecosystems. The long-term observations and experimental results confirmed that precipitation patterns and the herbaceous component were dominant drivers of the carbon dynamics in this phreatophyte-dominated desert ecosystem. This study illustrates the importance of inter-annual variations in climate and ecosystem composition for the carbon flux in arid and semiarid ecosystems. It also highlights the important effect of changing frequency and seasonal pattern of precipitation on the regional and global carbon cycle in the coming decades.

Key words: eddy covariance; net ecosystem carbon exchange; ecosystem respiration; gross ecosystem productivity; water-use strategy; halophyte desert community. 


\section{INTRODUCTION}

Arid and semi-arid ecosystems comprise more than $40 \%$ of the global terrestrial surface (Asner and others 2003; Poulter and others 2014) and are expanding due to global climate change and anthropogenic disturbance (Schlesinger and others 1990; Emmerich 2003). Although aboveground carbon concentrations are typically relatively low in arid and semi-arid ecosystems, these systems contain nearly $20 \%$ of the global soil carbon pool and account for $30-35 \%$ of terrestrial net primary productivity (UNSO/UNDP 1997; Field and others 1998). However, the carbon cycle in arid and semiarid ecosystems is poorly understood (Pacala and others 2001). Recent evidence suggests that the global carbon pool in semi-arid ecosystems is an increasingly important driver of the inter-annual variability of the global carbon cycle and that tropical rainforests may become less relevant drivers in the future (Poulter and others 2014). Therefore, assessing the impacts of vegetation and climate change on carbon cycling in these ecosystems has become a hot research topic in recent years (Barron-Gafford and others 2012; Jenerette and others 2012; De Graaff and others 2014; Scott and others 2014).

Climate change may impact strongly on ecological processes through a combination of direct climate-mediated changes in plant and microbial physiology, and more indirectly through climatemediated changes in vegetation composition (Barron-Gafford and others 2012, 2013; De Graaff and others 2014; Poulter and others 2014). Vegetation change is not simply an expansion or contraction of species' ranges but also strongly affects the biosphere-atmosphere exchange of water and carbon (Huxman and others 2005; Kulmatiski and Beard 2013; Scott and others 2014). For example, shrub $\left(\mathrm{C}_{3}\right.$ plants $)$ encroachment into $\mathrm{C}_{4}$-dominated grassland can lead to changes in the temperature response of leaf- to ecosystem-level carbon flux (Barron-Gafford and others 2012). Poulter and others (2014) found that a $6 \%$ expansion of vegetation cover in Australia was associated with a fourfold increase in the sensitivity of continental net carbon uptake to precipitation.

Desert ecosystems in Central Asia are dominated by phreatophytes, which depend on groundwater as their primary water source, and photosynthesis of these desert communities responds in a nonlinear fashion to growing season precipitation $(\mathrm{Xu}$ and Li 2006; Xu and others 2007). Moreover, the inter-annual variation of carbon flux may have resulted from an adjustment in community struc- ture to precipitation (that is, with more shallowrooted annual plants in wet years; Liu and others 2012). Huang and Li (2014) examined carbon exchange of the herbaceous layer using static chambers in the Gurbantonggut Desert of western China. They found that the herbaceous layer employed different water-use strategies over the course of the growing season, which affected the seasonal variation of carbon flux. If ephemeral plants, which use snowmelt water and spring precipitation, were dominant, the system was a carbon sink. In contrast, the abundance of annuals and perennials using summer precipitation resulted in the system being a carbon source in summer. Other research has shown that soil respiration increases greatly with precipitation, especially under shrubs (Ma and others 2012). Such studies to date have not assessed the mechanisms that result in the precipitation-driven patterns in the herbaceous layer and inter-annual variation of carbon flux over a phreatophyte-dominated desert ecosystem. Moreover, the long-term data are required to capture the strong inter-annual variability of precipitation in these systems and to fully understand how changes in climate and ecosystem composition affect the inter-annual variability of carbon exchange and their components.

Desert ecosystem community structure and productivity are highly sensitive to temporal variability in precipitation (Noy-Meir 1973; Reynolds and others 2004; Collins and others 2008; Fay 2009). In desert ecosystems of Central Asia, halophyte communities are ubiquitous and are typically divided into shallow- and deep-rooted species (Xu and $\mathrm{Li}$ 2006). These divergent rooting strategies allow the assessment of how changes in vegetation structure and function that depend on the different soil water pools affect carbon cycling. This study uses the long-term eddy covariance data and field experiments with the aim to (1) determine the inter-annual variation in the carbon flux of a phreatophyte-dominated desert ecosystem; (2) determine the inter-annual variation in the wateruse strategy of dominant shrubs; (3) assess how the herbaceous layer affects the inter-annual variation in ecosystem carbon flux; and (4) investigate how variations in precipitation patterns and other drivers affect the ecosystem carbon uptake and release. We hypothesized that precipitation patterns alter the community structure by changing the proportion of shallow-rooted annual plants; and that carbon cycling will be altered, as these plants make better use of precipitation and increase carbon accumulation. With these in mind, we hope to achieve a deep understanding of the impact of cli- 
matic changes on ecosystem structure and carbon cycling processes in phreatophyte-dominated desert ecosystems and resulting in better predictions under projected climatic change scenarios.

\section{Materials ANd Methods}

\section{Study Area}

Carbon and water fluxes, derived from eddy covariance data, were obtained at the Fukang Station of Desert Ecology, Chinese Academy of Sciences, located at the southern periphery of the Gurbantonggut Desert, in the hinterland of the Eurasian continent $\left(44^{\circ} 17^{\prime} \mathrm{N}, 87^{\circ} 56^{\prime} \mathrm{E}, 475 \mathrm{~m}\right.$ a.s.l.). The station is $8 \mathrm{~km}$ from the edge of the Gurbantonggut Desert and $72 \mathrm{~km}$ south of the highest peak of the eastern Tianshan Mountains (5445 $\mathrm{m}$ a.s.l.). The site is located on an alluvial plain with strongly saline/alkaline soils (electrical conductivity $>4, \mathrm{pH}>8.5$ for soil solution of soil:water ratio of 1:5). The site is fenced to prevent human disturbance and livestock grazing.

The plant community is dominated by the deeprooted desert shrub Tamarix ramosissima, which, as a phreatophyte, depends primarily on groundwater to survive (Xu and Li, 2006; Xu and others 2007). The shallow-rooted herbaceous component of the community is divided into two groups: spring annuals, and summer annuals and perennials. The spring annuals generally use snowmelt water and spring precipitation and are dominated by Alyssum linifolium, Schismus arabicus, Lactuca undulata, and
Erodium oxyrrhynchum (Fan and others 2013; Huang and Li 2014). Summer annuals and perennials (including Salsola nitraria, Suaeda salsa, Salicornia europaea, and Ceratocarpus arenarius) use summer precipitation as their main source of water. The study period (comprising 2002-2012, excluding years 2003 and 2010 due to instrument malfunction) was characterized by high inter-annual variation in plant canopy cover of the herbaceous layer (range 5-30\%). In this study, years with herbaceous cover higher than the 15-year (2000-2014) average of $13 \%$ are hereafter referred to as shrub-grass years (that is, the hydrological years 2002, 2004, 2007, 2008, and 2009). The other four hydrological years had a maximum plant cover below the average, and they are referred to as shrub years.

The site has a temperate continental arid climate, with an average annual temperature of $6.6^{\circ} \mathrm{C}$. The average annual precipitation is $163 \mathrm{~mm}$, around $60-75 \%$ of which falls in the growing season (May-October). Precipitation prior to the growing season (November-April) is mostly in the form of snow, which covers the soil for most of this period and melts in April. In this study, the growing season of each year was divided into 60-day blocks representing the beginning (May-June) (dominated by ephemeral plants), middle (July-August) (dominated by shrubs, annuals, and perennials), and end (September-October) (dominated by shrubs) (Figure 1).

Eddy covariance measurements were commenced at the site in 2002 (excluding 2003 and 2010, due to data logger malfunction). The system consisted of a 3 -

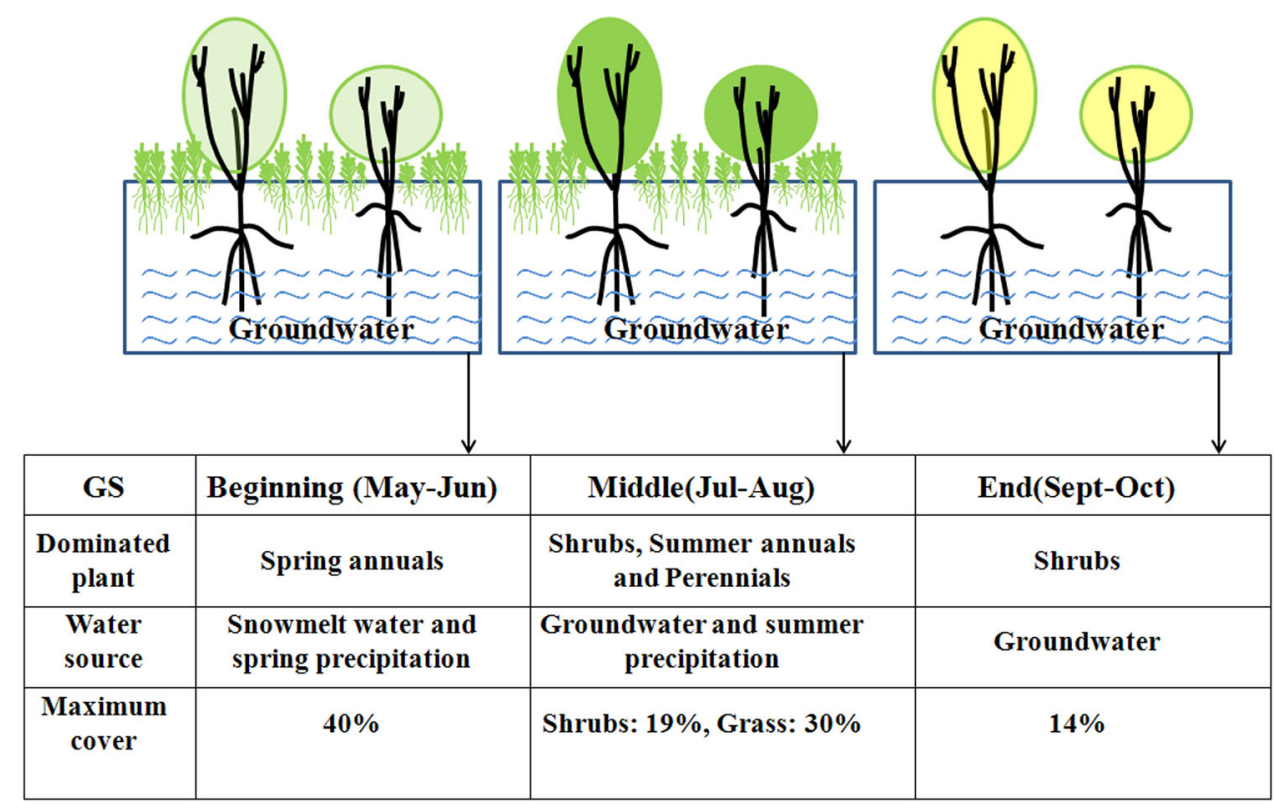

Figure 1. Conceptual diagram illustrating the dominant plant type, water source, and the maximum plant cover in different periods of the growing season (GS) at the study site (Fukang Station in western China). Different colors in shrub crowns indicate different growing stages (beginning: light green, middle: green, and end: yellow) (Color figure online). 
D ultrasonic anemometer-thermometer (STA-5055, KAIJO Corporation, Tokyo, Japan) and an open path infrared gas $\left(\mathrm{CO}_{2} / \mathrm{H}_{2} \mathrm{O}\right)$ analyzer (LI-7500, LI-COR Inc., Lincoln, Nebraska, USA) mounted at a height of $3 \mathrm{~m}$. The former measured instantaneous fluctuations of the horizontal $(u)$, vertical $(w)$, and lateral $(v)$ wind speed and the virtual temperature $\left(T_{\mathrm{a}}\right)$, whereas the latter measured instantaneous fluctuations in the concentration of carbon dioxide $(c)$ and water vapor $(q)$. The data were measured at $10 \mathrm{~Hz}$ and logged with a CR23X data logger (Campbell Scientific Inc., Logan, UT, USA). Additional meteorological instruments measured air temperature and humidity (MP300, Campbell Scientific Ltd., Shepshed, UK), soil temperature (107L, Campbell Scientific Inc., USA), photosynthetic active radiation (PAR), and net radiation ( $R_{\mathrm{n}}$ : LI-190SB, LI-COR Inc., Lincoln, Nebraska, USA). Two soil heat-flux plates (HFP01SC, Hukseflux, The Netherlands), installed $5 \mathrm{~cm}$ below the soil surface, measured soil heat flux. These data were logged with a CR23X data logger (Campbell Scientific Inc., USA).

\section{Data Processing}

\section{Data Post-processing}

The raw high-frequency $(10 \mathrm{~Hz})$ data were calculated using post-processing software (www.geos.ed.ac.uk/ abs/research/micromet/EdiRe developed by the University of Edinburgh, UK). Based on methods of Lee and others (2004), the computation routine included spike removal, planar rotation (Wilczak and others 2001), auto-detection of the time delay between different sensors, spectral correction for sensor separation and sensor path length, and Webb-Pearman-Leuning correction (Webb and others 1980). Net ecosystem carbon exchange (NEE) and latent and sensible heat were then calculated. To minimize calculation error, half-hour flux data were rejected if one of the following criteria was met: (1) incomplete half-hour measurements mainly caused by power failure, (2) rain events, (3) stable atmospheric conditions during night time $\left(u^{*}\right.$, friction velocity, $<0.1 \mathrm{~m} \mathrm{~s}^{-1}$ ), (4) half-hour data of NEE at night time $<0$, and (5) statistical outliers outside the \pm 5 standard deviation range of a 10-day running mean window. Approximately $30-40 \%$ of flux data were eliminated by the screening criteria, which caused data gaps at a rate consistent with other systems (Xu and Baldocchi 2004; Wohlfahrt and others 2008).

\section{Gap-Filling of the Eddy Covariance Data}

NEE was divided into day $\left(R_{\mathrm{n}}>1 \mathrm{~W} \mathrm{~m}^{-2}\right)$ and night $\left(R_{\mathrm{n}}<1 \mathrm{~W} \mathrm{~m}^{-2}\right)$ times. Negative NEE denotes net carbon uptake by the ecosystem. The following three strategies were used to fill gaps in the data: first, linear interpolation was used to fill gaps of $\leq 2 \mathrm{~h}$, and second for larger gaps during daytime, with a 15-day window, the relation between PAR and NEE was used to estimate the missing data using a Michaelis-Menten rectangular hyperbola (Ruimy and others 1995; Falge and others 2001):

$$
\mathrm{NEE}=\frac{\alpha \times \beta \times \mathrm{PAR}}{\alpha \times \mathrm{PAR}+\beta}-\gamma,
$$

where $\alpha$ is the initial slope of the light response curve ( $\mathrm{mol} \mathrm{CO} \mathrm{Col}^{-1}$ of photons), $\beta$ is the saturation value of NEE at infinite light level, and $\gamma$ is the bulk estimate of ecosystem respiration $\left(R_{\text {eco }}\right)$.

Third, for filling gaps in night measurements, we selected NEE values within a 30-day window from the gaps that were obtained under high turbulence conditions $\left(u^{*}>0.1 \mathrm{~m} \mathrm{~s}^{-1}\right.$, because the eddy covariance technique may underestimate NEE under stable atmospheric conditions at nighttime), and used the Lloyd-Taylor function (Lloyd and Taylor 1994):

$$
\mathrm{NEE}=a \times \exp \left(b \times T_{\text {soil }}\right),
$$

where $a$ and $b$ are the fitting coefficients and $T_{\text {soil }}$ is the soil temperature at $5 \mathrm{~cm}$.

\section{Calculating Gross Ecosystem Productivity and Ecosystem Respiration}

Gross ecosystem productivity (GEP) was obtained by subtracting NEE from $R_{\text {eco, }}$ which required evaluating $R_{\text {eco }}$ for day and night periods (Reichstein and others 2005).

\section{Energy Balance}

To assess the accuracy of the eddy covariance measurements, half-hourly data were used to calculate the surface energy budget for each of the 9 years of the study:

$$
R_{\mathrm{n}}-G=\mathrm{LE}+H,
$$

where $R_{\mathrm{n}}$ is the net radiation, $G$ is the soil heat flux, $\mathrm{LE}$ is the latent heat flux, and $H$ is the sensible heat flux. The extent to which the measured latent and sensible heat flux accounted for the available energy is shown in Table S1. Although the eddy covariance underestimated $\mathrm{LE}+\mathrm{H}$ (typically around $20-38 \%$ lower than $R_{\mathrm{n}}-G$ ), this energy balance closure was within the acceptable range (Twine and others 2000; Wilson and others 2002). The energy imbalance may be caused by soil heat 
flux in the upper soil layers, and the different locations of the footprints for the instruments used for soil heat flux and net radiation (Table S1).

\section{Error Estimate}

Uncertainties in annual NEE during the study period were estimated as a combination of errors arising from the worst-case estimate, gap-filling, and $u^{\star}$-filtering. The worst-case estimate of effects of random error on cumulative NEE was estimated according to equation (11) of Morgenstern and others (2004):

$$
\Delta \mathrm{NEE}=0.2 \sqrt{\sum_{i}^{n}\left(\left|\mathrm{NEE}_{i}\right| \Delta t\right)^{2}},
$$

where NEE is the random error for annual NEE associated with a $20 \%$ uncertainty of half $\mathrm{NEE}_{\mathrm{i}}$ and $t$ is the time (Wesely and Hart 1985). The gap-filling procedure described above resulted in a complete time series of NEE. Artificial noise was then added to the gap-filled data by randomly increasing or decreasing the values by $20 \%$ for daytime data, which corresponds approximately to the precision of half-hour flux measurements (Wesely and Hart 1985). We estimated uncertainties created by the gap-filling procedure by creating artificial gaps, as described in Giasson and others (2006). Artificial gaps (equal in number and size to those in the original dataset) were distributed randomly in the time series. The gap-filling procedure was applied again to the new data series, filling the artificially created gaps and allowing recalculation of the annual sums of NEE. Systematic errors associated with the choice of the $u^{*}$ threshold were estimated according to Morgenstern and others (2004). For different $u^{*}$ thresholds during night periods, the relationship between $T_{\text {soil }}$ and night NEE after $u^{*}$ filtering was used to model all night data below each $u^{*}$ threshold. Re-calculated annual sums of NEE then allowed the estimation of errors due to the choice of $u^{*}$ threshold.

\section{Determining the Water-Use Strategy of Dominant Shrubs}

Oxygen stable isotope measurements were used to determine the seasonal water-use strategy of the dominant shrub (T. ramosissima) during 2 years that differed greatly in precipitation (that is, 2009 and 2012).

\section{Sample Collection}

Four healthy $T$. ramosissima plants with average canopy size were randomly selected. During May-
October, one suberized twig from each plant was sampled twice at monthly intervals for xylem water. Cut twigs were quickly decorticated and placed into screw-cap glass vials sealed using Parafilm and stored in a freezer for xylem water extraction and isotopic analysis. At the same time, soil samples were collected adjacent to the sampled plants. Soil samples from 0 to $100 \mathrm{~cm}$ were obtained at $10-\mathrm{cm}$ intervals and from 100 to $300 \mathrm{~cm}$ were at 20 -cm intervals (the groundwater depth fluctuated within 3-5 m). Four replicates for each layer were sampled and sealed in glass vials and frozen for soil water extraction and isotopic analysis. Every month, groundwater samples were collected from a nearby well. After each precipitation event $(>5 \mathrm{~cm})$, precipitation samples were collected. Upon collection, water samples were sealed and stored in a freezer for analysis.

\section{Analysis and Calculation}

Xylem water and soil water were extracted using a cryogenic vacuum distillation extraction line and the extracted water was stored in sealed glass vials at $2^{\circ} \mathrm{C}$. The oxygen isotopic composition of the water was determined by a liquid water isotope analyzer (Equation 5) (LWIA, DLT-100, Los Gatos Research Inc., Mountain View, CA, USA). The $\delta^{18} \mathrm{O}$ values of the xylem water were corrected (following Schultz and others 2011) to eliminate the effect of methanol and ethanol contamination. More detailed procedures are described in $\mathrm{Wu}$ and others (2014) and Dai and others (2015)

$$
\delta^{18} O=\left(\frac{R_{\text {sample }}}{R_{\text {standard }}-1}\right) \times 1000 \%
$$

where $R_{\text {sample }}$ and $R_{\text {standard }}$ are the oxygen stable isotopic composition $\left({ }^{18} \mathrm{O} /{ }^{16} \mathrm{O}\right.$ molar ratio) of the sample and the standard water (Standard Mean Ocean Water), respectively.

The isotopic values of xylem water were compared with the potential water sources using the IsoSource model (Phillips and Gregg 2003) (http:// www.epa.gov/wed/pages/models/stableIsotops/iso source/isosource.htm). For each sample time, we calculated the mean and possible range of water utilization. Source increment was defined as $1 \%$, and mass balance tolerance was defined as $0.1 \%$. For details, see Wu and others (2014) and Dai and others (2015).

\section{Plant Cover and Leaf Area Survey}

Ten randomly located plots of $20 \mathrm{~m} \times 20 \mathrm{~m}$ were established to investigate deep-rooted shrub cover. At monthly intervals during the growing season (2002- 
2012), the widths of the all shrub crowns were measured in east-west and north-south directions, and shrub cover was calculated. At the same time, three sub-plots (each $1 \mathrm{~m} \times 1 \mathrm{~m}$ ) across the diagonal of the main plot were chosen to estimate the cover of the herbaceous layer using the point intercept method (Kershaw and Looney 1983). With 100 points measured per plot, the number of points that intercepted a part of the plant was counted and expressed as a percentage of the total number of points recorded.

To obtain seasonal dynamics of leaf area index (LAI) of the shrubs, LAI was determined at intervals of 2 weeks during the growing season in 2006 and 2007. On five average-sized plants, 10 well-growing branches were selected and labeled. All the leaves on each branch were photographed with a $6 \times 10^{8}$ pixel digital camera (Canon Inc., Tokyo, Japan). The total leaf surface area of each branch was calculated from the photographs using CI-400 CIAS software (Computer Imaging Analysis Software, CID Co., Logan, UT, USA). At the end of the growing season, the labeled branches were cut, and all leaves of the monitored plants were harvested. For each branch, the fresh and dry mass of leaves was determined to define the relationship between surface area and dry mass. On the basis of this relationship and the dry weight of the whole plant, we could establish the whole-shrub leaf area. LAI of the shrubs was then determined based on average plant density of the shrubs. For details, see $\mathrm{Xu}$ and others (2007) and Ma and others (2014).

\section{Statistical Analyses}

Data analyses, including errors calculations, linear regressions, and one-way analysis of variance, were performed with the statistical package SPSS for Windows (version 19.0, Chicago, IL, USA). Partial least square (PLS) regression analysis (Geladi and Kowalski 1986) was conducted to investigate the model component structure among the major drivers (independent variables including various measures of precipitation, light, temperature, vapor pressure deficit, plant cover, and growing season length) explaining the inter-annual variations of NEE, GEP, and $R_{\text {eco }}$ (dependent variables). The PLS analysis was carried out using SIMCA software v. 11.5 (UMETRICS, Umea, Sweden).

\section{RESULTS}

\section{Meteorological Conditions and Carbon Flux}

Figure 2 shows the variation of major meteorological conditions during the measurement period of 2002-2012 (excluding years 2003 and 2010). The seasonal trends of the daily averaged $R_{\mathrm{n}}$, air temperature $\left(T_{\mathrm{a}}\right)$ and soil temperature $\left(T_{\text {soil }}\right)$ were similar from year to year. Radiation varied from 10 to $-20 \mathrm{~W} \mathrm{~m}^{-2}$ on winter days and from 120 to $140 \mathrm{~W} \mathrm{~m}^{-2}$ in summer. Summer maximum and winter minimum air temperatures were in the ranges of $25-30$ and -20 to $-25^{\circ} \mathrm{C}$, respectively. Soil temperature was also similar across years with a summer maximum $\left(28-32^{\circ} \mathrm{C}\right)$ and winter minimum $\left(-7\right.$ to $\left.10^{\circ} \mathrm{C}\right)$. The mean annual $R_{\mathrm{n}}, T_{\mathrm{a}}$, and $T_{\text {soil }}$ were $49 \mathrm{~W} \mathrm{~m}^{-2}$ and 7 and $11^{\circ} \mathrm{C}$, respectively. Although mean annual precipitation over the 9 years $(153 \mathrm{~mm})$ was close to the long-term average (163 mm, 1985-2010), the inter-annual variation was large, ranging from $110 \mathrm{~mm}$ (recorded in 2008) to $231 \mathrm{~mm}$ (in 2007). Pre-growing season precipitation varied from $70 \mathrm{~mm}$ in 2002 to $18 \mathrm{~mm}$ in 2012 (Table 1). Pre-growing season precipitation was not significantly correlated with annual or growing season precipitation or the frequency of precipitation events (Pearson's $r<0.22$ ). Annually integrated NEE differed markedly between years, varying from a carbon sink in $2002\left(-91 \mathrm{~g} \mathrm{C} \mathrm{m}^{-2} \mathrm{y}^{-1}\right)$ to a carbon source in $2005\left(14 \mathrm{~g} \mathrm{C} \mathrm{m}^{-2} \mathrm{y}^{-1}\right)$ (Table 1$)$.

\section{Sensitivity of Inter-annual Variations in Carbon Flux}

We tested the effect of precipitation on carbon flux by using data from 2 years differing greatly in precipitation. The first year (2006) was dry, with annual precipitation $22 \%$ below the long-term $(163 \mathrm{~mm}$ ) and with $7 \%$ of herbaceous layer cover (considered a shrub year). The second year (2007) was wet $(42 \%$ above the long-term mean), with a high herbaceous layer cover of $25 \%$ (considered a shrub-grass year) (Figure 3A, F). The LAI of shrubs showed little variation during the two years $(F=0.11, P=0.75)$ (Figure 3E). The 2 years showed similar seasonal trends in NEE, GEP and $R_{\text {eco, }}$ but the cumulative values greatly differed. In the shrub year, the cumulative annual NEE, GEP, and $R_{\text {eco }}$ were $-5,111$, and $106 \mathrm{~g} \mathrm{C} \mathrm{m}^{-2} \mathrm{y}^{-1}$, respectively. In the shrubgrass year, the total values were $-40,220$, and $180 \mathrm{~g} \mathrm{C} \mathrm{m}^{-2} \mathrm{y}^{-1}$, respectively (Figure $3 \mathrm{~B}-\mathrm{D}$ ). The community was a weak sink or source in the shrub year $\left(-5 \pm 12 \mathrm{~g} \mathrm{C} \mathrm{m}^{-2} \mathrm{y}^{-1}\right)$ and a strong sink in the shrub-grass year $\left(-40 \pm 12 \mathrm{~g} \mathrm{C} \mathrm{m}^{-2} \mathrm{y}^{-1}\right)$ (Table 1).

\section{Water-Use Strategy of Dominant Shrubs}

Seasonal variations in the water-use strategy of the dominant shrub ( $T$. ramosissima) were determined 

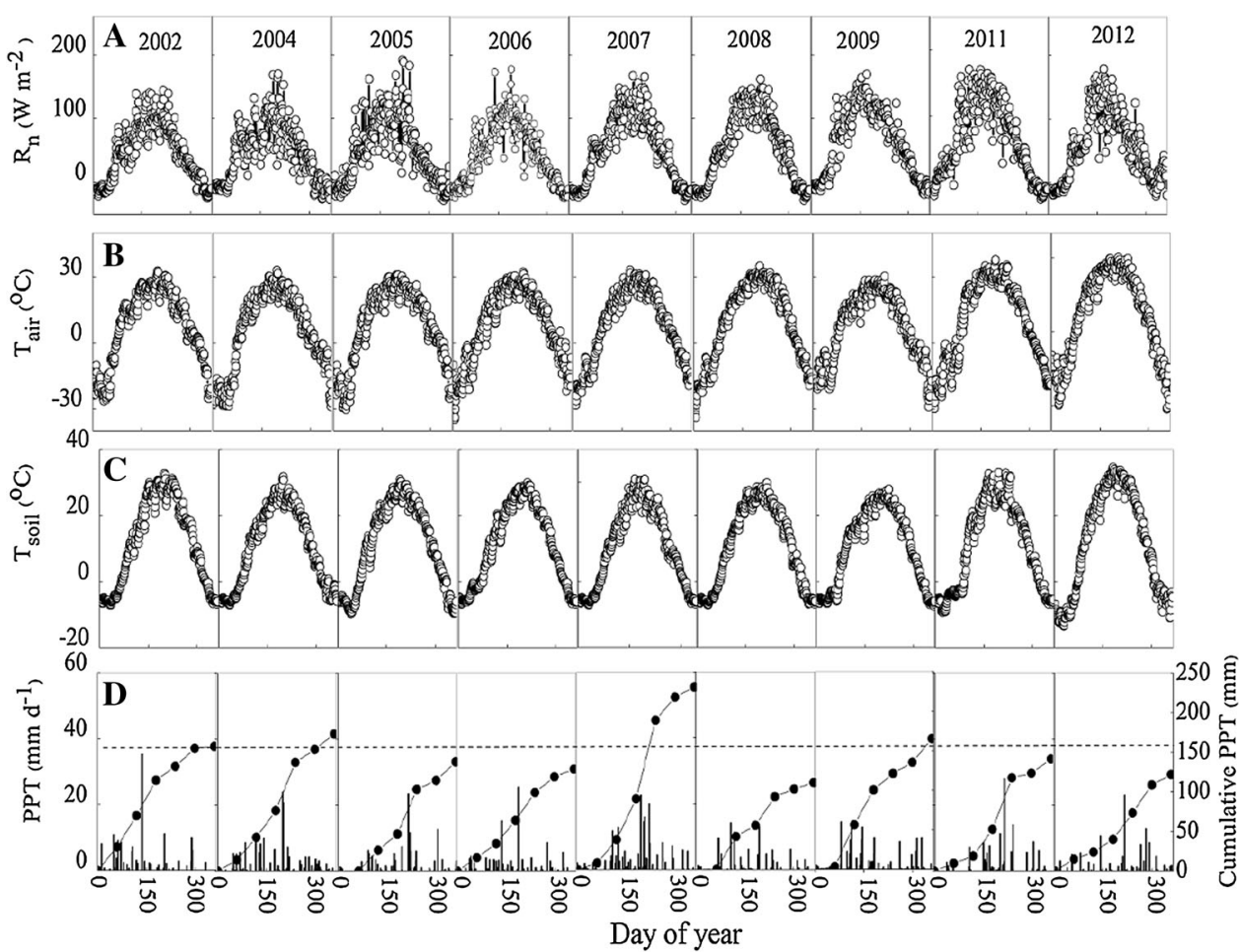

Figure 2. Seasonal and inter-annual variation in net radiation $\left(\mathrm{R}_{\mathrm{n}}\right)(\mathbf{A})$, air temperature $\left(T_{\text {air }}\right)(\mathbf{B})$, soil temperature $\left(T_{\text {soil }}\right)$ $(\mathbf{C})$, and precipitation (PPT) (D) at the study site. In (D), the bars indicate daily precipitation, filled circles indicate cumulative PPT, and the dashed line represents the long-term average annual PPT of $163 \mathrm{~mm}$.

Table 1. Total Annual and Pre-growing Season Precipitation (PPT), Total Number of Precipitation Events (Growing Season), Maximum Cover of the Herbaceous Layer and Net Ecosystem Carbon Exchange (NEE \pm Random and Systematic Errors as Assessed by the Error Analysis) in the Fukang Halophyte Desert Community

\begin{tabular}{llllll}
\hline Year & $\begin{array}{l}\text { Total PPT } \\
\left(\mathrm{mm} \mathrm{y}^{-1}\right)\end{array}$ & $\begin{array}{l}\text { Pre-growing season PPT } \\
\left(\mathrm{mm} \mathrm{season}^{-1}\right)\end{array}$ & $\begin{array}{l}\text { Number of PPT } \\
\text { events }(\#)\end{array}$ & $\begin{array}{l}\text { Max herbaceous } \\
\text { cover }(\%)\end{array}$ & $\begin{array}{l}\text { NEE } \\
\left(\mathrm{g} \mathrm{C} \mathrm{m}^{-2} \mathrm{y}^{-1}\right)\end{array}$ \\
\hline 2002 & 157 & 70 & 20 & 21 & $-91 \pm 20$ \\
2004 & 178 & 47 & 38 & 36 & $-49 \pm 17$ \\
2005 & 141 & 29 & 22 & 10 & $14 \pm 10$ \\
2006 & 123 & 41 & 19 & 7 & $-5 \pm 12$ \\
2007 & 231 & 39 & 36 & 25 & $-40 \pm 12$ \\
2008 & 110 & 49 & 24 & 18 & $-31 \pm 12$ \\
2009 & 165 & 58 & 28 & 16 & $-20 \pm 7$ \\
2011 & 141 & 34 & 15 & 7 & $-11 \pm 12$ \\
2012 & 122 & 18 & 13 & 8 & $-1.3 \pm 14$ \\
Mean & 153 & 43 & 24 & 16 & $-26 \pm 13$ \\
\hline
\end{tabular}

to assess if they may explain the striking variability in NEE, GEP, and $R_{\text {eco. }}$ Regardless of whether it was a shrub-grass (2009) or shrub year (2012), $T$. ramosissima used similar water sources (Figure 4): throughout the growing season, greater than $90 \%$ of the xylem water was derived from groundwater, with water sourced from middle to deep (50$180 \mathrm{~cm}$ ) soil comprising less than 10\% (Figure 4A, B). Additionally, the small seasonal changes in $\delta^{18} \mathrm{O}$ values of xylem water mirrored those seen in the groundwater with the values around $-11.5 \pm 0.1 \%$ (Figure 4C, D).

\section{Herbaceous Layer Control over Inter- annual Variations in Carbon Flux}

The seasonal dynamics of precipitation, plant cover, and ecosystem carbon and water fluxes showed similar trends in shrub-grass and shrub years for 2002-2012 (excluding 2003 and 2010, due to instrument malfunction), but the magnitude during the growing season differed strongly between the two types of years (Figure 5). Precipitation prior to and during the beginning of the growing season (day of year 60-180) differed between years 

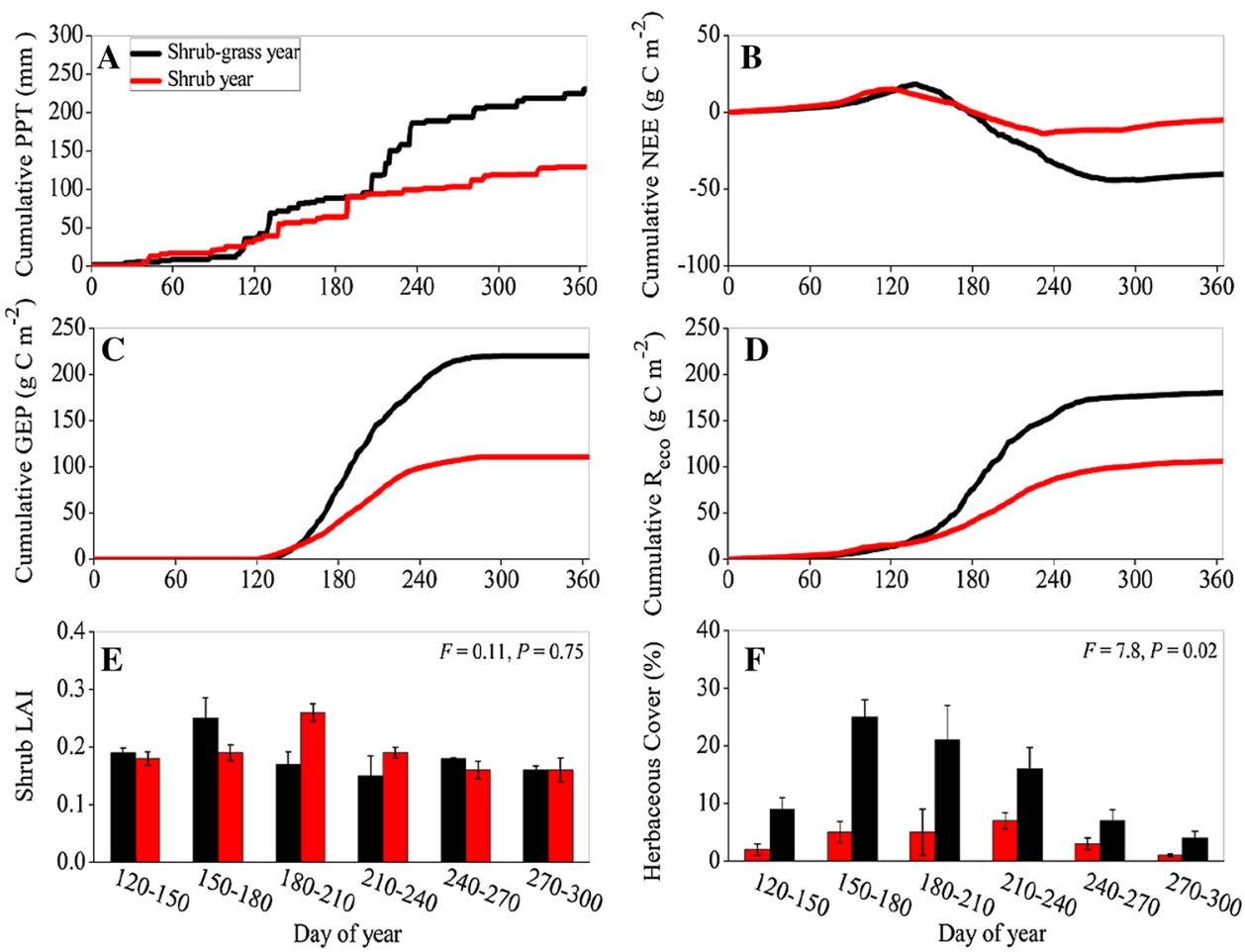

Figure 3. Comparison of cumulative annual precipitation (A), net ecosystem carbon exchange (NEE) (B), gross ecosystem productivity $(\mathrm{GEP})(\mathbf{C})$, ecosystem respiration $\left(R_{\text {eco }}\right)(\mathbf{D})$, seasonal dynamics of leaf area index (LAI) for shrubs $(\mathbf{E})$, and herbaceous cover (F) during shrub and shrub-grass years (2006 and 2007, respectively).

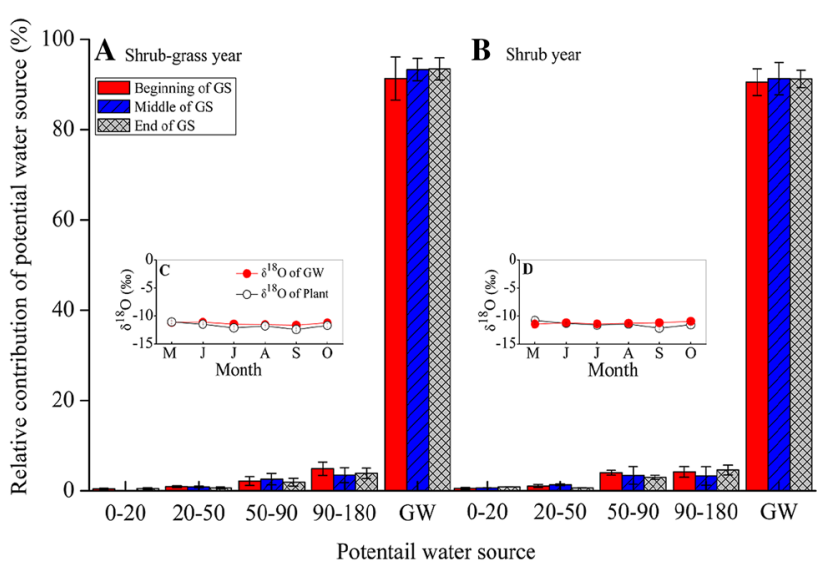

$(F=4.71, P=0.04)$, but precipitation during the middle and end of growing season (day of year 181300) did not $(F=0.02, P=0.89)$ (Figure 5A). Shrub cover did not differ between the two types of years $(F=0.01, P=0.93)$; however, the plant cover of the herbaceous layer significantly differed $(F=6.09$, $P=0.03$ ), reaching a maximum cover of $21 \%$ in the shrub-grass year and 6\% in the shrub years (Figure 5B). There was no significant difference between the daily average evapotranspiration for the
Figure 4. Seasonal changes in relative contribution of potential water sources for the dominant shrubs ( $T$. ramosissima) during shrubgrass (2009) (A) and shrub (2012) (B) years. The insets (C-D) show seasonal variations of oxygen stable isotope ratio $\left(\delta^{18} \mathrm{O}\right)$ value of stem water and groundwater. Error bars represent standard errors of the mean $(n=4)$. two types of years $(F=0.61, P=0.12)$ (Figure $5 \mathrm{C}$ ), but carbon fluxes (NEE, GE,P and $\mathrm{R}_{\text {eco }}$ ) differed between growing season periods in shrub-grass and shrub years. Maximum daily rates of NEE, GEP, and $R_{\text {eco }}$ were higher within the growing season in shrub-grass than in shrub years (NEE: $F=6.19$, $P=0.02$, GEP: $F=15.38, P=0.001, R_{\mathrm{eco}}: F=6.18$, $P=0.02$ ) (Figure 5D-F). Daily GEP in shrub-grass years was more than twice that in shrub years $(2.23$ and $0.97 \mathrm{~g} \mathrm{C} \mathrm{m}^{-2} \mathrm{~d}^{-1}$, respectively) (Figure 5E). 

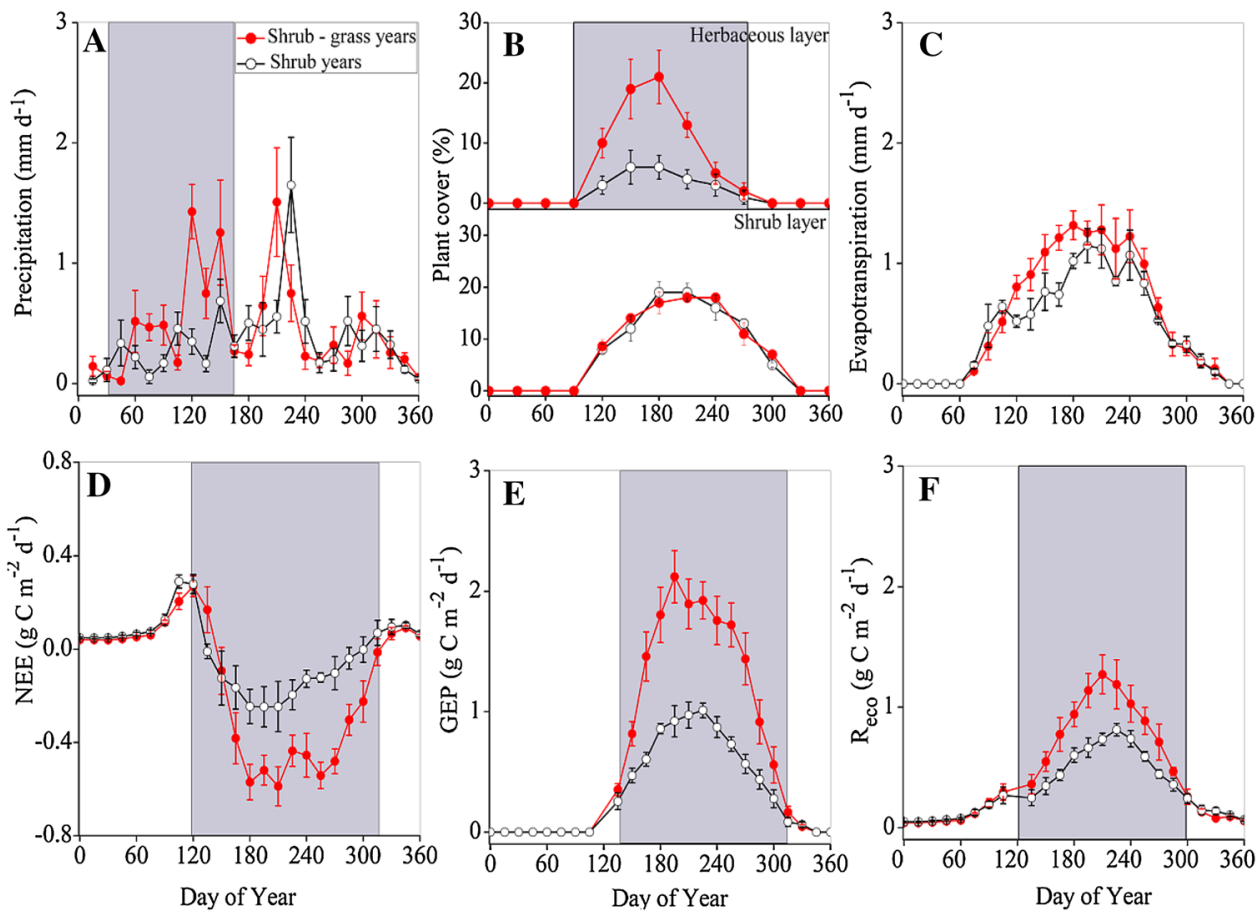

Figure 5. Average annual trends of precipitation $(\mathbf{A})$, plant cover $(\mathbf{B})$, evapotranspiration $(\mathbf{C})$, net ecosystem carbon exchange (NEE) (D), gross ecosystem productivity (GEP) (E), and ecosystem respiration $\left(R_{\text {eco }}\right)(\mathbf{F})$ during shrub-grass (2002, 2004 and 2007-2009) and shrub (2005, 2006, 2011, and 2012) years. Error bars represent standard errors. Gray panels represent significance in difference of variables in shrub-grass and shrub years $(P<0.05)$. Data presented are 15 day averages, except for plant cover which is presented on a 30-day interval.

\section{Relationship Between Precipitation Patterns and Carbon Fluxes}

Across all years, pre-growing season precipitation was significantly $(P<0.05)$ negatively correlated with annual NEE and growing season NEE $\left(R^{2}=0.72,0.68\right.$, respectively) (Figure 6A, B), indicating that increased pre-growing season precipitation increased annual and growing season carbon uptake. In contrast, pre-growing season precipitation was not significantly related with NEE outside the growing season $\left(R^{2}=-0.13\right.$, Figure $6 \mathrm{C}$ ). Additionally, pre-growing season precipitation was more strongly correlated with annual NEE and growing season NEE in shrub-grass than in shrub years (Figure 6).

Regressions of precipitation frequency (the number of growing season precipitation events) and annual GEP and GEP in the three growing season stages were significantly correlated, and the correlations were stronger in shrub-grass than in shrub years (Table 2). The correlations between precipitation frequency and $R_{\text {eco }}$ for the beginning and middle of the growing season and for the whole year were strongly significant in shrub-grass years $\left(R^{2}>0.75\right)$ and all pooled years together $\left(R^{2}>0.70\right)$ (Table 2). During the last stage of the growing season, there were no significant correlations between precipitation frequency and $R_{\text {eco }}$ for shrub-grass years, shrub years, or all years together (Table 2).

Total annual GEP was a stronger predictor of $R_{\text {eco }}$ in shrub-grass years $\left(R^{2}=0.95\right)$ and all years together $\left(R^{2}=0.87\right)$ (Table 2$)$ than in shrub years. In the beginning and middle of the growing season, GEP and $R_{\text {eco }}$ were significantly correlated in shrub-grass years $\left(R^{2}=0.95\right.$ and 0.95 , respectively) and all years together $\left(R^{2}=0.87\right.$ and 0.93 , respectively), but not in shrub years (Table 2). At the end of the growing season, none of these correlations were significant (Table 2).

\section{The Major Drivers of Inter-annual Variations in Carbon Fluxes}

Models of precipitation, PAR, temperature, vapor pressure deficit, plant cover, and growing season length explained 84,71 , and $74 \%$ of the variance in GEP, $R_{\text {eco, }}$ and NEE, respectively (Figure 7). Annual GEP and $R_{\text {eco }}$ showed the strongest positive 


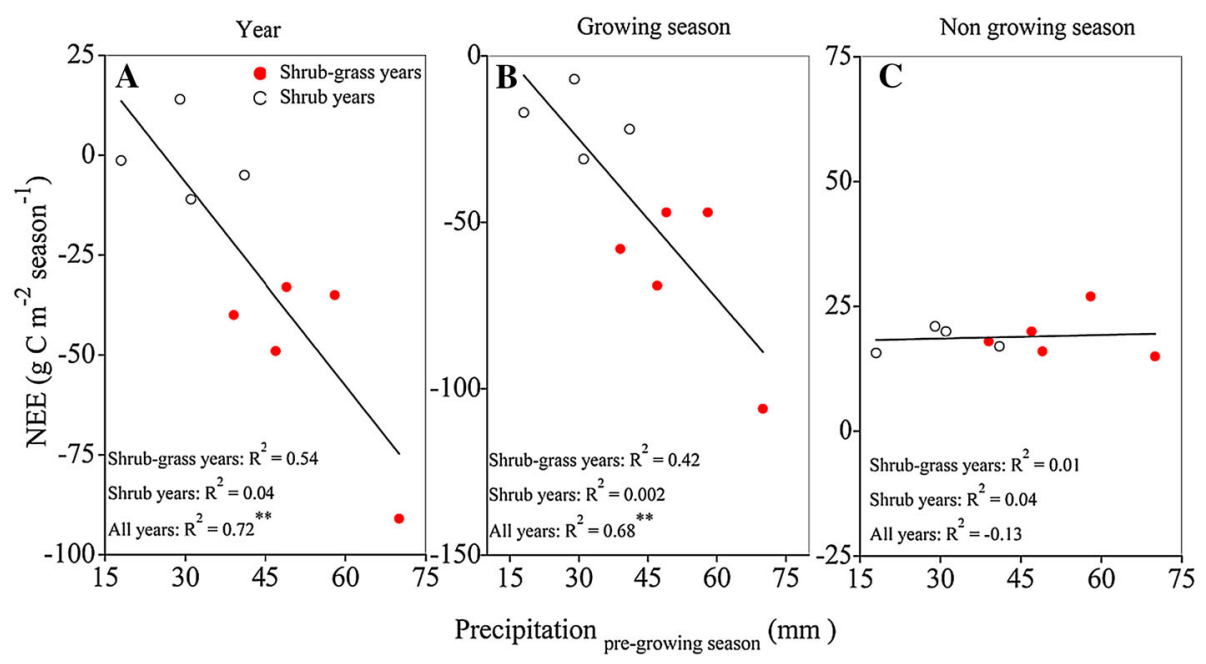

Figure 6. Relationships between pre-growing season precipitation and NEE for the all years together $(\mathbf{A})$, growing season (May-October) (B), and non-growing season (November-April) $(\mathbf{C})$ during the shrub-grass years (red circles) and shrub years (black open circles). Regression line is only for all years together. ' $* *^{\prime}$ represents statistically significant linear relationships for years $(P<0.05)$ (Color figure online).

Table 2. Linear Relationships Between Precipitation Frequency (PPT-freq; the Number of Growing Season Precipitation Events) and GEP and $R_{\text {eco, }}$ and Between GEP and $R_{\text {eco }}$ for the Whole Years, and the Three Stages of the Growing Season (GS): the Beginning (May-June), Middle (July-August), and End (September-October) of GS During the Shrub-Grass Years, Shrub Years, and All Years Together

\begin{tabular}{|c|c|c|c|c|c|c|}
\hline \multirow[t]{2}{*}{$\overline{\text { Varl }}$} & \multirow[t]{2}{*}{ Var2 } & \multirow[t]{2}{*}{ Type of year } & \multicolumn{4}{|c|}{ Part of year $\left(R^{2}\right)$} \\
\hline & & & Begin GS & Middle GS & End GS & Annual \\
\hline \multirow[t]{3}{*}{ GEP } & \multirow[t]{3}{*}{ PPT-freq } & Shrub-grass & 0.58 & 0.70 & 0.69 & 0.60 \\
\hline & & Shrub & 0.66 & 0.01 & 0.08 & 0.16 \\
\hline & & All & $0.65 * *$ & $0.79 * *$ & $0.58^{* *}$ & $0.72 * *$ \\
\hline \multirow[t]{3}{*}{$R_{\text {eco }}$} & \multirow[t]{3}{*}{ PPT-freq } & Shrub-grass & $0.74 * *$ & $0.77^{* *}$ & 0.54 & $0.76^{* *}$ \\
\hline & & Shrub & 0.05 & 0.05 & 0.80 & 0.05 \\
\hline & & All & $0.69 * *$ & $0.82 * *$ & 0.05 & $0.70^{* *}$ \\
\hline \multirow[t]{3}{*}{ GEP } & \multirow[t]{3}{*}{$R_{\text {eсо }}$} & Shrub-grass & $0.95 * *$ & $0.95^{* *}$ & 0.70 & $0.93 * *$ \\
\hline & & Shrub & 0.15 & 0.60 & 0.14 & 0.52 \\
\hline & & All & $0.87 * *$ & $0.93^{* *}$ & 0.16 & $0.87 * *$ \\
\hline
\end{tabular}

${ }^{* *}$ Represents statistically significant linear relationships for years $(P<0.05)$.

relationships with growing season precipitation frequency and plant cover (Figure 7A, B). Pregrowing season precipitation and plant cover were significantly negatively correlated with annual NEE (Figure 7C).

\section{Discussion}

Understanding the relationships between ecosystem structure and precipitation patterns and inter-annual variation of carbon flux is an important step towards predicting how future climate change will affect water and carbon cycles in arid and semi-arid ecosystems (Luo and others 2007; Ma and others 2007; Archibald and others 2009; Poulter and others 2014; Scott and others 2014). Using 10 years of eddy covariance data, we found that the carbon balance of a phreatophyte-dominated desert ecosystem responded strongly to variability in precipitation through changes in community structure.

Adjustments of community structure may have unexpected impacts on carbon flux (Polis and others 1997; Gutiérrez and others 2000; Holmgren and Scheffer 2001; Liu and others 2012). Our results showed that the strength of the phreatophytedominated desert ecosystem as a carbon sink was 


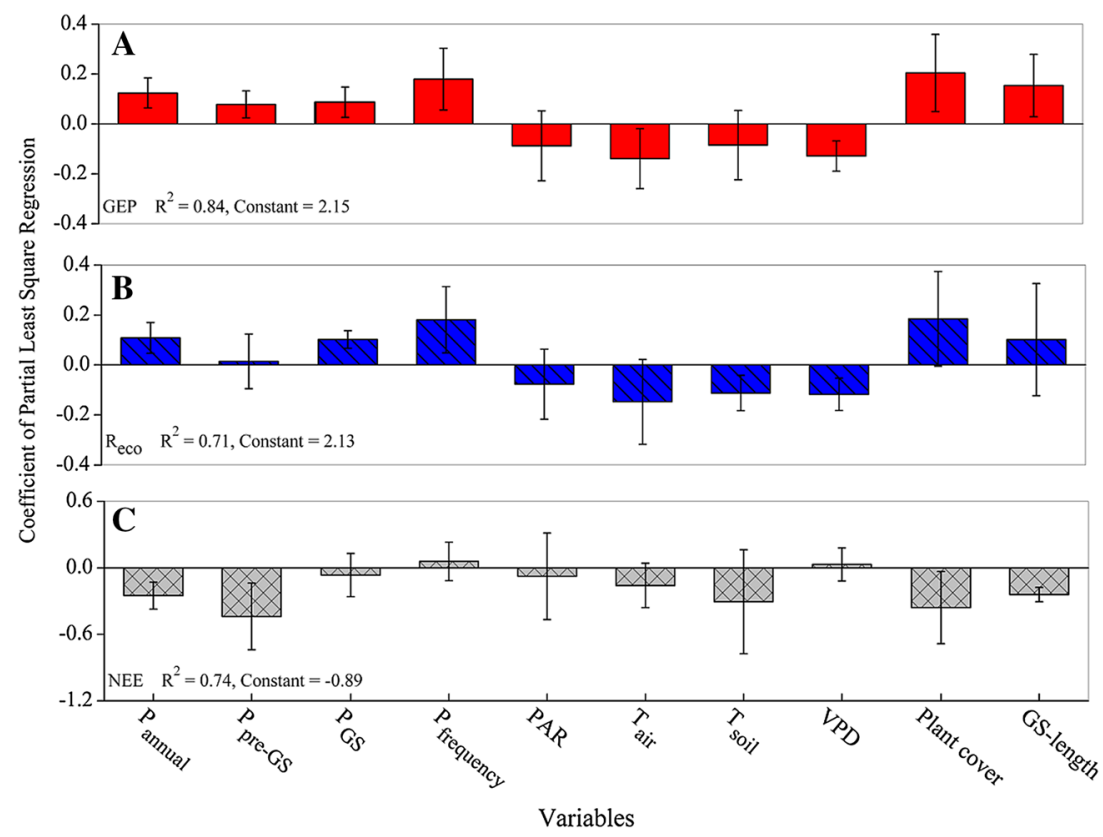

Figure 7. Partial least square (PLS) component coefficients of variables explaining annual gross ecosystem productivity $(\mathrm{GEP})(\mathbf{A})$, annual ecosystem respiration $\left(R_{\mathrm{eco}}\right)(\mathbf{B})$, and annual net ecosystem carbon exchange (NEE) (C), GEP, and $R_{\mathrm{eco}}$ are both presented as positive fluxes. $P_{\text {annual }}$ total annual precipitation; $P_{\text {pre-GS }}$ pre-growing season precipitation; $P_{G S}$ growing season precipitation; $P_{\text {frequency }}$ growing season precipitation frequency (the number of growing season precipitation events); $P A R$ photosynthetic active radiation; $T_{\text {air }}$ air temperature; $T_{\text {soil }}$ soil temperature at depth of $5 \mathrm{~cm}$; $V P D$ vapor pressure deficit; plant cover: cover of herbaceous layer; GS-length: growing season length (defined as extending from the day assimilation first occurred to the day when ecosystem carbon assimilation stopped, from about day of year 121 to 290 ). $R^{2}$ values are for all variables combined.

linked to the annual precipitation pattern (Figures 3 and 5). The main component of this community was a deep-rooted shrub that relied strongly upon groundwater throughout the entire growing season (Figure 4), and was therefore unlikely to be the driver of the precipitation-driven inter-annual variability in carbon flux (Xu and $\mathrm{Li}$ 2006; Xu and others 2007). Instead, years with increased precipitation before the growing season were associated with an increased plant cover of shallow-rooted annual plants. The increase in GEP in these shrubgrass years was stronger than the increase in $R_{\text {eco, }}$ which resulted in a strong annual carbon uptake, compared with a mostly carbon neutral (weak carbon source or sink) in shrub years (Figure 5).

Greater pre-growing season precipitation leads to an increased ecosystem carbon uptake in shrubgrass years, likely due to the emergence and growth of shallow-rooted annual plants (Figures 5 and 6). At our study site, pre-growing season precipitation is mostly in the form of snow, which accumulates throughout winter and melts in early spring when temperature increases (Zhou and others 2012). The snowmelt functions similar to one event of heavy rainfall in early spring: it re-fills the soil water stor- age and occurs just in time to facilitate the emergence and growth of shallow-rooted annual plants (Fan and others 2013). The emerged shallow-rooted annual plants can use the spring and summer precipitation, which, in turn, increases ecosystem productivity (Ehleringer and others 1991; Golluscio and others 1998; Scott and others 2000; Hamerlynck and others 2012, 2013; Fan and others 2013). In addition, these shallow-rooted annual plants increase the canopy cover, which reduces bare soil evaporation and thus increases net ecosystem carbon uptake and water-use efficiency (Liu and others 2012). Hence, higher precipitation before the growing season results in greater fractions of spring annuals, which leads to a higher contribution to the ecosystem productivity and higher water-use efficiency (Huang and Li 2014).

During the growing season in shrub-grass years (but not in shrub years), precipitation frequency was significantly correlated with GEP and $R_{\text {eco }}$ (Table 2). The results suggest that growing season GEP was determined in large part by growing season precipitation frequency, with abundant precipitation events causing increased carbon uptake (Xu and Baldocchi 2004; Ivans and others 2006). 
The increase in $R_{\text {eco }}$ with more precipitation events was caused by rapid increases in heterotrophic respiration (Huxman and others 2004; Ma and others 2012) and increases in autotrophic respiration of shallow-rooted annual plants following precipitation events (Table 2) (Reichstein and others 2003; Verburg and others 2004). In this phreatophyte-dominated desert, sufficient pregrowing season precipitation leads to more germination and growth of shallow-rooted annual plants. When the soil is subsequently frequently recharged, the herbaceous component will remain active (Reynolds and others 2004; Collins and others 2008) and strongly affect the carbon balance of the ecosystem.

Our study showed that any changes in the frequency, seasonal pattern, and inter-annual variation of precipitation had strong indirect impacts on the carbon flux in this phreatophyte-dominated desert ecosystem by affecting the relative contributions of shrub and herbaceous components. The productivity and water-use efficiency of arid and semi-arid ecosystems are generally considered low compared with mesic ecosystems (Kochendorfer and others 2011). However, the net ecosystem carbon uptake during shrub-grass years in the phreatophyte-dominated desert reported here are similar to those of semi-arid rangelands across North America (Ma and others 2007; Svejcar and others 2008). In shrub-dominated desert ecosystems, the productivity from herbaceous plants (shallow-rooted species) is more variable within and between years than from shrubs, as the herbaceous plants are more sensitive to precipitation (Austin and others 2004; Schwinning and others 2004; Bell and others 2012). For example, pre-growing season precipitation may trigger germination of shallow-rooted species, but this may not translate into ecosystem carbon accumulation, unless subsequent spring and summer precipitation allows seedlings to survive and grow. However, without germination of shallow-rooted species in early spring, subsequent precipitation in spring and summer may either be evaporated from bare soil or be used by shrubs (Huxman and others 2004; Peng and others 2013). Therefore, although our study focused on a phreatophyte-dominated desert ecosystem, our conclusions may still be applicable in principle to many other shrub-dominated desert ecosystems with a significant herbaceous layer.

Most of China has seen a significant decreasing trend in the amount and frequency of precipitation over the last 50 years (Zhang and Cong 2014). Climate change over the next few decades is also predicted to result in a reduction of the duration and depth of snow cover, which will affect snowmelt and recharge of soil water storage (Shi and others 2011). Moreover, the frequency and seasonal distribution of precipitation is expected to change, and droughts will be more common across the country (Kharin and others 2007; Knapp and others 2008; Hoerling and others 2011). Such changes are likely to affect vegetation dynamics and ecosystem processes, including carbon uptake (Kulmatiski and Beard 2013; Scott and others 2014), but the response will be spatially variable (Golodets and others 2013). If the patterns found in this phreatophytedominated desert ecosystem are representative of some other arid and semi-arid ecosystems, precipitation variability may thus have a large impact on the regional and global carbon balance in the future.

\section{ACKNOWLEDGEMENTS}

The financial support was provided by the Strategic Priority Research Program of China (XDA05030500), the National Natural Science Foundation of China (41201041, 41301279), and the "Western Light" program of the Chinese Academy of Science (XBBS201204). We thank all staff of the Fukang Station of Desert Ecology for their excellent field and laboratory assistance.

\section{REFERENCES}

Archibald SA, Kirton A, Merwe MR, van der Scholes RJ, Williams CA, Hanan N. 2009. Drivers of inter-annual variability in net ecosystem exchange in a semiarid savanna ecosystem, South Africa. Biogeosciences 6:251-66.

Asner GP, Archer S, Hughes RF. 2003. Net changes in regional woody vegetation cover and carbon storage in Texas drylands, 1937-1999. Glob Change Biol 9:316-35.

Austin AT, Yahdjian L, Stark JM, Belnap J, Porporato A, Norton U, Ravetta DA, Schaeffer SM. 2004. Water pulses and biogeochemical cycles in arid and semiarid ecosystems. Oecologia $141: 221-35$.

Barron-Gafford GA, Scott RL, Jenerette GD, Hamerlynck EP, Huxman TE. 2013. Landscape and environmental controls over leaf and ecosystem carbon dioxide fluxes under woody plant expansion. J Ecol 101:1471-83.

Barron-Gafford GA, Scott RL, Jenerette GD, Hamerlynck EP, Huxman TE. 2012. Temperature and precipitation controls over leaf- and ecosystem-level $\mathrm{CO}_{2}$ flux along a woody plant encroachment gradient. Glob Change Biol 18:1389-400.

Bell TW, Menzer O, Troyo-Diéquez E, Oechel W. 2012. Carbon dioxide exchange over multiple temporal scales in an arid shrub ecosystem near La Paz, Baja California Sur, Mexico. Glob Change Biol 18:2570-82.

Collins SL, Sinsabaugh RL, Crenshaw C, Green L, Porras-Alfaro A, Stursova M, Zeglin LH. 2008. Pulse dynamics and microbial processes in aridland ecosystems. J Ecol 96:413-20.

Dai Y, Zheng XJ, Tang LS, Li Y. 2015. Stable oxygen isotopes reveal distinct water use patterns of two Haloxylom species in the Gurbantonggut Desert. Plant Soil 389:73-87. 
De Graaff MA, Throop HL, Verburg PSJ, Arnone JA, Campos X. 2014. A synthesis of climate and vegetation cover effects on biogeochemical cycling in shrub-dominated drylands. Ecosystems 17:931-45.

Ehleringer JR, Phillips SL, Schuster WSF, Sandquist DR. 1991. Differential utilization of summer rains by desert plants. Oecologia 88:430-4.

Emmerich WE. 2003. Carbon dioxide fluxes in a semiarid environment with high carbonate soil. Agric For Meteorol 116:91-102.

Falge E, Baldocchi D, Olson R, Anthoni P, Aubinet M, Bernhofer C, Burba G, Ceulemans R, Clement R, Dolman H, Granier A, Gross P, Grünwald T, Hollinger D, Jensen NO, Katul G, Keronen P, Kowalski A, Ta Lai C, Law BE, Meyers T, Moncrieff J, Moors E, Munger JW, Pilegaard K, Rannik U, Rebmann C, Suyker A, Tenhunen J, Tu K, Verma S, Vesala T, Wilson K, Wofsy S. 2001. Gap filling strategies for defensible annual sums of net ecosystem exchange. Agric For Meteorol 107:43-69.

Fan LL, Tang LS, Wu LF, Ma J, Li Y. 2013. The limited role of snow water in the growth and development of ephemeral plants in a cold desert. J Veg Sci 25:681-90.

Fay PA. 2009. Precipitation variability and primary productivity in water-limited ecosystems: how plants 'leverage' precipitation to 'finance' growth. New Phytol 181:5-8.

Field C, Behrenfeld M, Randerson J, Falkowski P. 1998. Primary production of the biosphere: integrating terrestrial and oceanic components. Science 281:237-40.

Geladi P, Kowalski BR. 1986. Partial least-squares regression: a tutorial. Anal Chim Acta 185:1-17.

Giasson MA, Cousolle C, Margolis HA. 2006. Ecosystem-level $\mathrm{CO}_{2}$ fluxes from a boreal cutover in eastern Canada before and after scarification. Agric For Meteorol 140:23-40.

Golluscio RA, Sala OE, Lauenroth WK. 1998. Differential use of large rainfall events by shrubs and grasses: a manipulative experiment in the Patagonian steppe. Oecologia 115:17-25.

Golodets C, Sternberg M, Kigel K, Boeken B, Henkin Z, Seligman NG, Ungar ED. 2013. From desert to Mediterranean rangelands: will increasing drought and inter-annual rainfall variability affect herbaceous annual primary productivity? Clim Change 119:785-98.

Gutiérrez JR, Arancio G, Jaksic FM. 2000. Variation in vegetation and seed bank in a Chilean semi-arid community affected by ENSO 1997. J Veg Sci 11:641-8.

Hamerlynck EP, Scott RL, Barron-Gafford GA, Cavanaugh ML, Moran MS, Huxman TE. 2012. Cool-season whole-plant gas exchange of exotic and native semiarid bunchgrasses. Plant Ecol 213:1229-39.

Hamerlynck EP, Scott RL, Barron-Gafford GA. 2013. Consequences of cool-season drought-induced plant mortality to Chihuahuan desert grassland ecosystem and soil respiration dynamics. Ecosystems 16:1178-91.

Hoerling M, Hurrell J, Kumar A, Terray L, Eischeid J, Pegion P, Zhang T, Quan XW, Xu TY. 2011. On North American decadal climate for 2011-2020. J Clim 24:4519-28.

Holmgren M, Scheffer M. 2001. El Niño as a window of opportunity for the restoration of degraded arid ecosystems. Ecosystems 4:151-9.

Huang G, Li Y. 2014. Phenological transition dictates the seasonal dynamics of ecosystem carbon exchange in a desert steppe. J Veg Sci 26:337-47.

Huxman TE, Snyder K, Tissue D, Leffler AJ, Pockman W, Ogle K, Sandquist D, Potts DL, Schwinning S. 2004. Precipitation pulses and carbon balance in semi-arid and arid ecosystems. Oecologia 141:254-68.

Huxman TE, Wilcox BP, Breshears DD, Scott RL, Snyder KA, Small EE, Hultine K, Pockman WT, Jackson RB. 2005. Ecohydrological implications of woody plant encroachment. Ecology 86:308-19.

Ivans S, Hipps L, Leffler AJ, Ivans CY. 2006. Response of water vapor and $\mathrm{CO}_{2}$ fluxes in semiarid lands to season and intermittent precipitation pulses. J Hydrometeor 7:995-1010.

Jenerette GD, Barron-Gafford GA, Guswa AJ, Mcdonnell JJ, Villegas JC. 2012. Organization of complexity in water limited ecohydrology. Ecohydrology 5:184-99.

Kharin VV, Zwiers FW, Zhang X, Hegerl GC. 2007. Changes in temperature and precipitation extremes in the IPCC ensemble of global coupled model simulations. J Clim 20:1419-43.

Knapp AK, Beier C, Briske DD, Classen AT, Luo YQ, Reichstein M, Smith MD, Smith SD, Bell JE, Fay PA. 2008. Consequences of more extreme precipitation regimes for terrestrial ecosystems. Bioscience 58:811-21.

Kochendorfer J, Castillo EG, Haas E, Oechel WC, Paw KT. 2011. Net ecosystem exchange, evapotranspiration and canopy conductance in a riparian forest. Agric For Meteorol 151:544-53.

Kulmatiski A, Beard KH. 2013. Woody plant encroachment facilitated by increased precipitation intensity. Nat Clim Change 3:833-7.

Kershaw KA, Looney JH. 1983. Quantitative and dynamic plant ecology. London: Edward Arnold.

Lee X, Massman M, Law B. 2004. Handbook of micrometeorology. A guide for surface flux measurement and analysis. Boston: Kluwer Academic.

Liu R, Pan LP, Jenerette GD, Wang QX, Cieraad E, Li Y. 2012. High efficiency in water use and carbon gain in a wet year for a desert halophyte community. Agric For Meteorol 162 163:127-35.

Lloyd J, Taylor JA. 1994. On the temperature dependence of soil respiration. Funct Ecol 8:315-23.

Luo H, Oechel WC, Hastings SJ, Zulueta R, Qian Y, Kwon H. 2007. Mature semiarid chaparral ecosystems can be a significant sink for atmospheric carbon dioxide. Glob Change Biol 13:386-96.

Ma J, Liu R, Tang LS, Lan ZD, Li Y. 2014. A downward $\mathrm{CO}_{2}$ flux seems to have nowhere to go. Biogeosciences 11:6251-62620.

Ma J, Zheng XJ, Li Y. 2012. The response of $\mathrm{CO}_{2}$ flux to rain pulses at a saline desert. Hydrol Process 26:4029-37.

Ma S, Baldocchi DD, Xu L, Hehn T. 2007. Inter-annual variability in carbon dioxide exchange of an oak/grass savanna and open grassland in California. Agric For Meteorol 147:15771.

Morgenstern K, Black TA, Humphreys ER, Griffis TJ, Drewitt GB, Cai T, Nesic Z, Spittlehouse DL, Livingston NJ. 2004. Sensitivity and uncertainty of the carbon balance of a Pacific Northwest Douglas-fir forest during an El Niño/La Niña cycle. Agric For Meteorol 123:201-19.

Noy-Meir I. 1973. Desert ecosystems: environment and producers. Annu Rev Ecol Syst 4:25-52.

Pacala SW, Hurtt GC, Baker D, Peylin P, Houghton RA, Birdsey RA, Heath L, Sundquist ET, Stallard RF, Ciais P, Moorcroft P, Caspersen JP, Shevliakova E, Moore B, Kohlmaier G, Holland E, Gloor M, Harmon ME, Fan SM, Sarmiento JL, Goodale CL, Schimel D, Field CB. 2001. Consistent land-and atmospherebased U.S. carbon sink estimates. Science 292:2316-20. 
Peng SS, Piao SL, Shen ZH, Ciais P, Sun ZZ, Chen SP, Bacour C, Peylin P, Chen AP. 2013. Precipitation amount, seasonality and frequency regulate carbon cycling of a semi-arid grassland ecosystem in Inner Mongolia, China: a modeling analysis. Agric For Meteorol 178:46-55.

Phillips DL, Gregg JW. 2003. Source partitioning using stable isotopes: coping with too many sources. Oecologia 136:261-9.

Polis GA, Hurd SD, Jackson CT, Sánchez Piñero F. 1997. El Niño effects on the dynamics and control of an island ecosystem in the Gulf of California. Ecology 78:1884-97.

Poulter B, Frank D, Ciais P, Myneni RB, Andela N, Bi J, Broquet G, Canadell JG, Chevallier F, Liu YY. 2014. Contribution of semi-arid ecosystem to interannual variability of the global carbon cycle. Nature 509:600-3.

Reichstein M, Falge E, Baldocchi D, Papale D, Aubinet M, Berbigier P, Bernhofer C, Buchmann N, Gilmanov T, Granier A, Grunwald T, Havrankova K, Ilvesniemi H, Janous D, Knohl A, Laurila T, Lohila A, Loustau D, Matteucci G, Meyers T, Miglietta F, Ourcival JM, Pumpanen J, Rambal S, Rotenberg E, Sanz M, Tenhunen J, Seufert G, Vaccari F, Vesala T, Yakir D, Valentini R. 2005. On the separation of net ecosystem exchange into assimilation and ecosystem respiration: review and improved algorithm. Glob Change Biol 11:1424-39.

Reichstein M, Rey A, Freibauer A, Tenhunen J, Valentini R, Banza J, Casals P, Cheng Y, Grünzweig J, Irvine J, Joffre R, Law B, Loustau D, Miglietta F, Oechel W, Ourcival JM, Pereira JS, Peressotti A, Ponti F, Qi Y, Rambal S, Rayment M, Romanya J, Rossi F, Tedeschi V, Tirone G, Xu M, Yakir D. 2003. Modeling temporal and large-scale spatial variability of soil respiration from soil water availability, temperature and vegetation productivity indices. Glob Biogeochem Cycles 17:104. doi:10.1029/2003GB002035.

Reynolds JF, Kemp PR, Ogle K, Fernandez RJ. 2004. Modifying the 'pulse-reserve' paradigm for desert of North America: precipitation pulses, soil water, and plant responses. Oecologia 141:194-210.

Ruimy A, Jarvis PG, Baldocchi DD, Saugier B. 1995. CO $\mathrm{CO}_{2}$ fluxes over plant canopies and solar radiation: a review. Adv Ecol Res 26:1-51.

Schlesinger WH, Reynolds JF, Cunningham GL, Huenneke LF, Jarrell WM, Virginia RA, Whitford WG. 1990. Biological feedbacks in global desertification. Science 247:1043-8.

Schultz NM, Griffis TJ, Lee XH, Baker JM. 2011. Identification and correction of spectral contamination in ${ }^{2} \mathrm{H} /{ }^{1} \mathrm{H}$ and ${ }^{18} \mathrm{O} /{ }^{16} \mathrm{O}$ measured in leaf, stem, and soil water. Rapid commun Mass Spectrom 25:3360-8.

Schwinning S, Sala OE, Loik ME, Ehleringer JR. 2004. Thresholds, memory, and seasonality: understanding pulse dynamics in arid/semi-arid ecosystems. Oecologia 141:191-3.

Scott RL, Huxman TE, Barron-Gafford GA, Jenerette GD, Young JM, Hamerlynck EP. 2014. When vegetation change alters ecosystem water availability. Glob Change Biol 20:2198-210.

Scott RL, Shuttleworth WJ, Goodrich DC, Maddock T. 2000. The water use of two dominant vegetation communities in a semiarid riparian ecosystem. Agric For Meteorol 105:241-56.
Shi Y, Gao XJ, Wu J, Giorgi F. 2011. Changes in snow cover over China in the 21 st century as simulated by a high resolution regional climate model. Environ Res Lett 6:045401.

Svejcar T, Angell R, Bradford JA, Dugas W, Emmerich W, Frank AB, Gilmanov T, Haferkamp M, Johnson DA, Mayeux $H$. 2008. Carbon fluxes on North American Rangelands. Rangel Ecol Manag 61:465-74.

Twine TE, Kustas WP, Norman JM, Cook DR, Houser PR, Meyers TP, Prueger JH, Starks PJ, Wesely ML. 2000. Correcting eddycovariance flux underestimates over a grassland. Agric For Meteorol 103:279-300.

UNSO/UNDP (1997) Aridity zones and dryland populations: an assessment of population levels in the world's drylands. New York, UNSO/UNDP.

Verburg PJ, Arnone JA, Obrist D, Evans RD, Leroux-Swarthout D, Johnson DW, Luo Y, Coleman JS. 2004. Net ecosystem carbon exchange in two experimental grassland ecosystems. Glob Change Biol 10:498-508.

Webb EK, Pearman GI, Leuning R. 1980. Correction of flux measurements for density effects due to heat and water vapor transfer. Q J R Meteorol Soc 106:85-100.

Wesely ML, Hart RL. 1985. Variability of short-term eddy-correlation estimates of mass exchange. In: Hutchision BA, Hicks BB, Eds. The forest-atmosphere interaction. Dordrecht: Reidel. p 591-612.

Wilczak JM, Oncley SP, Stage SA. 2001. Sonic anemometer tilt correction algorithms. Boundary-Layer Meteorl 99:127-50.

Wilson K, Goldstein A, Falge E, Aubinet M, Baldocchi D, Berbigier P, Bernhofer C, Ceulemans R, Dolman H, Field C, Grelle A, Ibrom A, Law BE, Kowalski A, Meyers T, Moncrieff J, Monson R, Oechel W, Tenhunen J, Valentini R, Verma S. 2002. Energy balance closure at FLUXNET sites. Agric For Meteorol 113:223-43.

Wohlfahrt G, Fenstermaker LF, Arnone JA. 2008. Large annual net ecosystem $\mathrm{CO}_{2}$ uptake of a Mojave Desert ecosystem. Glob Change Biol 14:1475-87.

Wu Y, Zhou H, Zheng XJ, Li Y, Tang LS. 2014. Seasonal changes in the water use strategies of three co-occurring desert shrubs. Hydrol Process 28:6265-75.

Xu H, Li Y. 2006. Water-use strategy of three central Asian desert shrubs and their responses to rain pulse events. Plant Soil 285:5-17.

Xu H, Li Y, Xu GQ, Zou T. 2007. Ecophysiological response and morphological adjustment of two Central Asian desert shrubs towards variation in summer precipitation. Plant Cell Environ 30:399-409.

Xu LK, Baldocchi DD. 2004. Seasonal variation in carbon dioxide exchange over a Mediterranean annual grassland in California. Agric For Meteorol 1232:79-96.

Zhang XY, Cong ZT. 2014. Trends of precipitation intensity and frequency in hydrological regions of China from 1956 to 2005. Glob Planet Chang 117:40-51.

Zhou HF, Zheng XJ, Zhou BJ, Dai Q, Li Y. 2012. Sublimation over seasonal snowpack at the southeastern edge of a desert in central Eurasia. Hydrol Process 26:391 1-20. 